\title{
ХУДОЖНІ ОБРАЗИ ПІР РОКУ ПОЕЗІЇ В. СВІДЗІНСЬКОГО: ЛЕКСИКО-СИНТАКСИЧНИЙ АСПЕКТ
}

У статті проаналізовано мовні засоби вираження часових вимірів річного циклу на лексичному та синтаксичному рівнях у їхній взаємодіі. З'ясовано, що для відтворення відповідних темпоральних образів В. Свідзінський однаковою мірою послуговується як простими, так і складними синтаксичними конструкціями. Прості речення та предикативні частини складних найчастіше ускладнено однорідними членами, серед яких превалюють однорідні присудки. Досліджено, що в поетичному доробку автора річний час представлений усіма порами року, але В. Свідзінський найчастіше зображуе весну та осінь. Художні словообрази окресленого часу є багатогранними, наповненими філософією буття та переживаннями ліричного героя.

Ключові слова: індивідуальний стиль, словесний образ, речення, однорідні члени, порівняння, повтор, звертання.

Smetana I. I. Literary Images of Seasons in V. Svidzinskyi’s Poetry: Lexical and Syntactic Aspects. The article analyzes language means of expressing the annual measurements of the annual cycle at the lexical and syntactic levels in their interaction.

The actuality of the proposed research is due to the fact that literary time in the poetic language of $V$. Svidzinskyi is represented by various temporal lexemes and syntactic constructions, research of which in the interaction of the above levels allows to see the entire depth of the author's individuality presented in the verbal-aesthetic picture of the world, which is not yet specially researched.

The purpose of the article is to characterize the linguistic means of expression of the seasons in V. Svidzinskyi's poetry at the lexical and syntactic levels. In this regard, the tasks are set as follows: to analyze the verbalization of the time dimensions of the annual cycle; to find out what lexical-syntactical means reveal and highlight the time described in the author's poetry.

It has been found out that in order to reproduce the corresponding temporal images, $V$. Svidzinskyi equally used both simple and complex syntactic constructions. Simple sentences and predicative parts of the complex ones are often complicated by homogeneous parts, among which homogeneous predicate prevail. It has been investigated that in the poetic work of the author the annual time is represented by all of seasons, but $V$. Svidzinskyi most often depicts the spring and autumn, which represent the richness of meaningful nuances. Literary word-makers of the given time are multifaceted, filled with the philosophy of being and feelings of the lyrical hero.

Key words: individual style, wordly image, sentence, homogeneous parts, comparison, repetition, appeal.

\section{Вступ}

Світобачення митця завжди пов’язане з його часовідчуттям, бо час є одним із ключових атрибутів існування людини, джерелом їі досвіду, об'єктом свідомого чи позасвідомого «переживання» (Лавринович, 2013: 101). У поезії В. Свідзінського різні часові виміри належать до активно відображуваних об'єктів, що відзначають дослідники його творчості (А. Тимченко (2010), О. Старова (2011), Е. Соловей (2006)).

Різні аспекти поетичної мови В. Свідзинського аналізують І. Барчишина (2013), С. Богдан (2017), О. Волковинський (2006), Ю. Громик (2003), Н. Данилюк (2017), Т. Левчук (2017), А. Мединська (2017) та ін. 
Актуальність пропонованої студії зумовлена тим, що художній час у поетичній мові В. Свідзінського репрезентовано різними темпоральними лексемами та синтаксичними конструкціями, дослідження яких у взаємодії окреслених рівнів дає змогу побачити всю глибину авторської індивідуальності, представленої у вербально-естетичній картині світу, що на сьогодні ще не становило предмет спеціального дослідження.

Мета статті - схарактеризувати засоби вираження пір року в поетичній творчості В. Свідзінського на лексичному та синтаксичному рівнях. У зв'язку із цим поставлено такі завдання: здійснити аналіз вербалізації часових вимірів річного циклу; з'ясувати, якими лексико-синтаксичними засобами розкривається та увиразнюється окреслений час у поезії автора.

\section{Методи й методики дослідження}

Комплексний підхід зумовив застосування відповідних методів дослідження: метод контекстного аналізу, орієнтований на виявлення експресивно-змістових функцій мовних одиниць у поетичному тексті; структурно-семантичного аналізу (для розгляду семантики мовних одиниць, що формують авторське поетичне мовлення); інтерпретаційний - для декодування змісту повідомлюваного; описовий метод, що передбачає процедури загального аналізу, систематизації та інтерпретації досліджуваних мовних явищ.

\section{Результати та дискусії}

Пори року в поетичному доробку В. Свідзінського здебільшого є засобом розкриття внутрішнього світу та переживань ліричного героя, зображення минулого та проминальності часу. Художня репрезентація часу у творчості В. Свідзінського пов'язана з активним уживанням лексем зима, весна, літо, осінь. Ці слова в аналізованих поезіях набувають як узагальненочасового виміру, так і конкретно-особистісного. Як зауважує Ю. Лотман, «символіка пір року - одна з найбільш загальних та різноманітних у смисловому відношенні. Пов'язана з філософією природи, ідеєю циклічності <...>, вона є мовою, зручною для вираження універсальних метафізичних понять» (Лотман, 1996: 511).

За нашими спостереженнями, серед назв пір року найактивніше функціює весна. Цей словообраз як об'єкт порівняння поєднується з незабутнім образом коханої ліричного суб'єкта: В моїй уяві образ твій, / Осяяний любов 'ю і весною, / Неначе сонячний навій, / Обвинений блакиттю молодою (В. Свідзінський). Відокремлені постпозитивні означення посилюють ліричний струмінь. Крім того, поет підносить образ коханої над земним існуванням, використовуючи градацію: любов (земне почуття) - весна - сонячний навій блакить.

Поет передає думки ліричного героя та його душевний стан, пов'язаний з образом милої: Так ти на мене вієш чаром / I радістю тії весни, / Коли мов сонячним пожаром / Юнацькі обнялися сни, / І вихор буйно-золотий / Промчався по душі моій, / I в тій тривозі чарівній / Запломенився світоч твій (В. Свідзінський). У цьому контексті ампліфікація підрядних означальних частин до опорного слова весна передає почуття зворушення. Слова чар і padicms 
перебувають у кінці та на початку рядків відповідно, тому є акцентованими в смисловому й інтонаційному планах. В одному семантичному ключі витримано словосполучення сонячним пожаром, вихор буйно-золотий, тривога чарівна та граматичне ядро запломенився світач, що метафорично передають максимальний вияв почуттів. Компоненти наведених словосполучень переважно містять сему 'світити', 'горіти'.

Образ весни розкриває внутрішній світ ліричного героя й у такому контексті: Я хвилююсь, ніяк не звикну / До ніжної темряви, до весни (В. Свідзінський). Для увиразнення бентежного стану автор ускладнює структуру речення однорідними присудками та додатками. Однорідний ряд об’єктних поширювачів об'єднує мотив кохання.

Єдність і взаємозв'язок минулого і майбутнього В. Свідзінський актуалізує, зіставляючи ці поняття в межах однієї поезії та репрезентуючи їх словами весна, осінь: Загубився в небі слід весни, / День задумався ясний <...> Чую в сериі звук нових тремтінь - / Потайну осінню тінь (В. Свідзінський). Зауважимо, що в цитованій поезії не названо лексему літо. Автор начебто навмисно пропускає цю пору року, оскільки розуміє, що в душі ліричного героя вже немає місця для тепла, сонця й радості.

Епітет весняний, у свою чергу, означує словообрази рай, ранок, потік; весняні сади, свята, тобто й абстрактні поняття, і темпоральні та локативні. Весняні пейзажні замальовки В. Свідзінський поєднує зі спогадами про молодість, як-от: Юний голос до схід сония чути: / На південнім обрію весна / Одчинила двері днів погідних, / I верба сіяє край потока, / Пахощами віючи далеко - / I в гаю склонився білий сон, / Пийте мого чистого вина (В. Свідзінський). Словообраз весна поєднує часопросторові площини: обрій, верба, потік, гай, з одного боку, і схід сония, дні - з другого. Автор використовує полісиндетон, підкреслюючи таким чином відкриту структуру частин, поєднаних сурядним зв'язком.

Весна змальовується метафорично за асоціацією з водним простором, наприклад: Прислухайся: десь за горою, / За верховинами дерев, / Облоки ронять краплі світла / В уважні розплески весни (В. Свідзінський). Поет використовує відокремлені уточнювальні локативні обставини, що позначають верх земного простору та словообрази небесного простору (облоки, краплі світла). Таке поєднання створює верхню проекцію зображення, змальовуючи весну водночас як атмосферне явище.

Розвій весни передано таким метафоричним образом: Аж коли весна розсвітиться, / І весь світ обвіє голубо, / І протеплить тіло велетня / До осердя потаєнного - / Гарне листя вільно скине він [дуб] (В. Свідзінський). Паралель між часовими та просторовими образами надає вислову яскравого емоційно-експресивного забарвлення й створює цілісну поетичну картину. У контексті використано дистантний коренеслівний повтор розсвітиться - світ, що разом з однорідними присудками передає процес поширення весни.

В. Свідзінський використовує протиставлення словообразів вербова віта цвіте, що символізує весну й розвій, та жовта свіча горить, що символічно позначає згасання життя: За безлистим деревом саду, / Як дві нерідних 
сестри, / Вербова віта цвіте / I жовта свіча горить. / Вербова віта цвіте - / На весну, на юний шум, / А навіщо ия жовта свіча? (В. Свідзінський). Автор поєднує ці образи порівнянням і повтором зі зміною комунікативної мети речення з розповідної на питальну.

За допомогою ампліфікації однорідних підметів створено ліричну картину природи навесні в перспективі, що накреслюється дієсловом-присудком у формі майбутнього часу буде, але при цьому зіставлення здійснюється з минулим: I буде знову, як бувало: / Весна, і вечір, і тепло, / I проліски ламке стебло, / I мирне галяви кружало (В. Свідзінський). Використаний полісиндетон логічно й інтонаційно виокремлює кожен з однорідних членів.

Словесні образи на позначення весни функціюють у складі порівнянь до різних суб'єктів: А ти ж наповнено світилась, / Як бростка навесні (В. Свідзінський); І так гримлять [поїди], мов тішаться весною / I відталлю (В. Свідзінський). Підрядними порівняльними частинами створено індивідуально-авторські образи.

Загалом у творчості письменника образ весни є поліаспектним, оскільки відтворює і плинність часу, і колообіг життя. Риторичні запитання із цим ключовим словом градаційно посилюють думку й виконують емоційно-експресивну роль: Хто мені повість, у які безодні / Углибає час? Де весна прихильна, / Що ввела мене в двері повноліття, / В вік юнацтва? (В. Свідзінський). Експресії контексту надають бажальні речення, що містять розгорнуті метафори: «Не згасав би ніколи наряд / Весни іліта, о ні! / Верховець на буланім коні, / Не сваволив би листопад» (В. Свідзінський).

Словообраз осінь за активністю функціювання в поезії В. Свідзінського дещо поступається образу весна, але є надзвичайно важливим елементом його поетичної картини світу. Художній образ осені має багатозначне потрактування, хоч переважно асоціюється зі швидкоплинністю життя, смутком за молодістю й минулими роками.

Ця пора року набуває в поетичній мові здебільшого негативних конотацій, наприклад: А вже поля мої пусті; / У парку клени золоті, / I осінь віє непривітно (В. Свідзінський). Для змалювання осені автор використовує в перших двох предикативних частинах іменні складені присудки, структура яких дає можливість передавати статичні ознаки в плані їх констатування. I навіть ознака золотий, що має опоетизовувати образ осені, не підтримується подальшим контекстом. Ця пора року наділена ознакою до присудка непривітно. Подана пейзажна картина символізує завмирання: Щось жалібно шепоче гай / I ронить листя. / Листя миле, / Прощай, прощай (В. Свідзінський). Для створення експресії поет використовує повтор-підхоплення, змінюючи функцію іменника листя з об'єкта дії на звертання, що посилює його смислову активність. Ознаки жалібно, милий та предикат прощай вносять потужний ліричний струмінь і драматизм у зображуване.

У контексті поезії «І цей листочок...» осінь постає нищівною силою: $\mathrm{Ta}$ осінь повіє / Холодом зорнім, / Блиском зловісним, / I він поникне, / I рідна гілка / Віддасть покірно / Свою дитину / Землі байдужій (В. Свідзінський). Характеристику осені подано через однорідні об'єктні поширювачі до предиката 
nовіє, поєднані з означеннями, серед яких (блиском) зловісним має негативне оцінне значення.

Інверсія підмета осінь та наділення його ознакою заздрісна слугують посиленню негативних характеристик темпорального компонента в такому реченні: Не веліла осінь заздрісна, / Щоб дерева величалися / Спадком літа добромисного: / Все обірване, обтрушене! (В. Свідзінський). Остання предикативна частина за допомогою ампліфікації однорідних іменних присудків ніби підсумовує руйнівні дії осені.

Словообраз осінь постає символом завмирання життя в такому потужному образі: Ти як осінь - поникла така! / Сухий безсмертник - твоя рука (В. Свідзінський). Іменник осінь стає об'єктом порівняння коханої, життя якої згасає. Через зіставлення з осінніми реаліями передано також нещасливу долю ліричного героя: Як древо, осінню обняте, Живий вінок наш облетів (В. Свідзінський). Іменник осінь функціює у відокремленому означенні й тому набуває більшої виразності. У контексті взаємодіють народнопоетичні образи (древо, вінок), що символізують життя.

Ліричний герой усвідомлює незворотність життя, що теж передано через зіставлення з природними процесами восени: Не мріє осінь у діброві / Заздріти ивічену черемху, / I я не мрію, що колись / Ти знов повернешся до мене (В. Свідзінський). Синтаксичний паралелізм та однаковий предикат мріє посилюють зіставлення осені та ліричного суб'єкта.

Вірш «Відколи сховав я мертву голубку...» завершується філософським діалогом з осінню: - Осінь, осінь, де моя голубка? / - Ходи до мене, стань під рукою, / Як тебе кину на дурний вихор, / Забудеш ходити, голубки питати!.. / Сонцю леліти, рікам шуміти, / Мені, осені, хороше гуляти, / А потужному дубові довгий вік, / А опалому листю зойк та зик, / А твойй голубці тихо лежати, / В янтарні очі тьми набирати... (В. Свідзінський). Синтаксична організація контексту нагадує замовляння, з якими добре був обізнаний В. Свідзінський. Низка предикативних частин із головним членом у формі інфінітива в останньому реченні передає невідворотність того, що відбувається у світі. У репліці-відповіді осінь погрожує ліричному героєві, забороняючи шукати того, що відійшло, бо це небезпечно для нього самого.

Образ осені експлікує в ліриці В. Свідзінського і всеосяжний смуток: Сядеш спочити на камінь - Навколо осінь, жура (В. Свідзінський), що репрезентує локатив навколо та метафоричне поєднання в однорідному ряду підметів осінь і жура.

Безсполучниковою складною конструкцією оформлено словообраз осінь, який традиційно позначає вік людини: Не дивися в юний зір таємний, / Не діймайся милої руки: / Ходить осінь по саду твоєму, / Обтрясає зоряні гіл$\kappa и$ (В. Свідзінський). Перша предикативна частина $є$ загальнозаперечною, бо заперечення стосується однорідних головних членів означено-особового речення. Друга частина передає причинові змістові відношення, і в ній подано розгорнутий метафоричний образ осені як суб'єкта дії. Те, що це словесний образ людського віку, засвідчує словосполучення по саду твоєму.

Неодноразово епітетом осінній означено назви різних явищ природи, 
які надають контексту «сумного» звучання: Лежить вона в корені темної ялини, / Як тонкий місяць при хмарі осінній (В. Свідзінський); Чую в сериі звук нових тремтінь - / Потайну осінню тінь (В. Свідзінський); Лежиш у ярі, $i$ осінній лист / Тебе, як гріб забутий, засипає (В. Свідзінський).

Письменник майстерно відтворює зміну пір року, як-от: Півнеба осінь прилягла, / Півнеба - в володінні літа (В. Свідзінський). Автор унаочнює передання часової межі, уживаючи в першій предикативній частині підмет осінь, а в другій - об’єктний поширювач літо, єднальною ланкою слугує повторювана синтаксема півнеба.

На позначення словообразу осінь та іiі реалій В. Свідзінський створює перифрастичні вислови: Ще осінь, пломениста квітка, / Гойдає зламаним стеблом (В. Свідзінський); О осінь, мрії ж⿻рної любов! (В. Свідзінський); Осінні хмари, / Жоржини вечірнього неба! <... > Осінні хмари, / Опале листя 3 дерева світла! (В. Свідзінський). Перший перифраз передає колірне забарвлення осіннього пейзажу, а те, що осінь образно йменується квіткою, зумовлене утілюваним мотивом спогаду про кохану.

Картини літа в ліриці В. Свідзінського трапляються рідше, ніж весни й осені: Лімо, йдучи попереду / Кроком легким і живим, / Розставляло чаші меду / На обрусі польовім (В. Свідзінський). Оцінна семантика словообразів літа є позитивною. Епітетом літній В. Свідзінський означує явища природи, простір, наприклад: Так чисто віє вечір літній, / Коли квітує жито (В. Свідзінський); І широчіє літній степ (В. Свідзінський).

У поезії «Спогад»: На землі настигає літо, / На землі ясмин ивіте, / Світ-дуга поринає / В голубе й золоте (В. Свідзінський) - ужито багатокомпонентний анафоричний повтор синтаксеми на землі та двочленний повтор предикативної частини ( На землі настигає літо) для створення цілісного метафоричного образу часопростору. Субстантиви у функції локативних обставин (в голубе й золоте) набувають значення кольорів національної символіки.

Метафорично вжиті дієслова-присудки підкреслюють рух часу, який минає без вороття: Не лічить літо сонячних годин, / Нечутно дні спливаються в сторіччя (В. Свідзінський). У граматичному й смисловому ядрі першої предикативної частини закцентовано увагу на тому, що саме влітку час минає найшвидше.

Ампліфікація підметів створює панорамну картину благодатного літа, що виринає у спогадах: Снилось / Сонце їй в глибокому потоці, / Під запоною рослин листатих, / I дитинство, і село, і літо, / I гарячі пахощі покосу, / I в городі золото крокосу (В. Свідзінський). Полісиндетон, що об'єднує об'єктні поширювачі, дає змогу відбити ритмомелодику безконечних спогадів.

На відміну від літа, словообраз зима неодноразово асоціюється зі смертю та смутком. За допомогою антитези, яку автор створює порівняннями, зосереджено увагу на безжиттєвості мрій ліричного героя: У той-бо час ивіли ви, як лелії, / А нині ви, як цей зимовий иявіт (В. Свідзінський). Митець, увиразнюючи сумну дію часу, означує її обставиною способу дії смутно: Смутно дзвонить зима / Намерзлим віттям дерев (В. Свідзінський). 
В. Свідзінський через оживлення зими та надання негативних рис їі діям репрезентує народні уявлення про те, що взимку природа засинає, а земля відпочиває до весни: Три тополі / Стоять, як перше; на старій стодолі / Зима кроквину вивела на світ, / Розтріпавши трухлявий околіт (В. Свідзінський). Задля увиразнення згаданої пори року та ії̈ нищівної сили В. Свідзінський виносить лексему зима в підмет й ускладнює безсполучникове складне речення відокремленою обставиною способу дії.

У перифразі на позначення зими, який поширює звертання, підкреслено ознаки тривалості та скутого стану взимку: Снігур гуде, снігур гуде в саду / Про тебе, зимо, довгая неволе (В. Свідзінський).

Використовуючи в поезії «Вранці іній як сніг» складне безсполучникове речення з протиставленням, поет увиразнює змалювання зими: 3-за ріки, від луки, / Лине клекіт гусей, / 3-за ріки - / Гусім пухом зима... / Тьма (В. Свідзінський). Автор змальовує прихід зими, що асоціюється з порожнечею, холодом. Для самого ж ліричного героя зима - це передчуття розлуки з прекрасним і водночас печальним для нього світом.

Перші рядки вірша «Взимі, на світанні...» створюють повтор-обрамлення. В. Свідзінський не тільки акцентує увагу на часі (взимі) відтворюваних подій, а й розкриває незрозумілі почуття, які наповнюють ліричного героя: Взимі, на світанні, / Коли сосни вгрібаються лапами в сніг, / А чола підносять у світло, / Солодко прикувати себе до тиші / Твоєї холодної душі - / Такою мужсністю віє від неї! (В. Свідзінський). Лексема взимі має контекстуальне значення холоду, завмирання, а на світанні - розквіту й початку. Цей контраст упродовж вірша підтримується конструкціями: вгрібаються лапами в сніг чола підносять у світло, що містять контекстуальні антоніми. Глибину образу передано складним реченням з різними видами зв'язку: однорідні підрядні частини, поєднані між собою протиставними змістовими відношеннями, посилюють темпоральний план зображення, а частина, приєднувана безсполучниковим зв'язком, виразно розкриває причину попередньої частини.

\section{Висновки}

Отже, у поетичній мові В. Свідзінського функціюють словообрази з назвами всіх пір року: весна асоціюється з коханням, дитинством та юністю ліричного героя; літо - з радістю буття природи, тому й мають вони позитивне смислове навантаження; осінь та зима передають швидкоплинність життя, смуток за минулим, нездійсненність мрій. Найактивніше функціюють художні образи весни та осені, які репрезентують багатство змістових нюансів. Особистісні переживання В. Свідзінським складних життєвих обставин вилилися у високохудожні словесні образи, дослідження яких дає змогу глибше розкрити особливості його поетичного ідіостилю.

\section{ЛIТЕРАТУРА}

1. Барчишина I. Енжамбеман як засіб емфатизації епітетних структур у поетичних творах М. Волошина та В. Свідзінського. Слово і час. 2013. № 2. С. 60-67. 2. Богдан С. Звертання в поетичних текстах Володимира Свідзінського. Волинь філологічна: текст і контекст: зб. наук. праць. Луцьк: Східноевропейський нац. ун-т імені Лесі 
Українки, 2017. С. 8-17. 3. Бондаренко А. І. Образна семантика темпоральності українських поетичних текстів XX століття в інтегративному вияві: дис. ... докт. філол. наук: 10.02.01. Київ, 2017. 489 с. 4. Волковинський О. Місце і значення епітета в архітектоніці балад В. Свідзінського. Наукові праці Кам'янець-Подільського державного університеmy. Філологічні науки. 2006. Вип. 13. С. 205-214. 5. Громик Ю. В. Діалектні елементи в художньому мовленні Володимира Свідзінського. Творчість Володимира Свідзінського: зб. наук. праць. Луцьк: РВВ «Вежа» Волин. держ. ун-ту імені Лесі Українки, 2003. С. 114-145. 6. Данилюк Н. О. Архетипні мовні образи в поезії Володимира Свідзінського. Волинь філологічна: текст і контекст: зб. наук. праць. Луцьк: Східноевропейський нац. ун-т імені Лесі Українки, 2017. С. 63-75. 7. Лавринович Л. Модуси часу у структурі ліричних творів Т. Шевченка. Волинь філологічна: текст і контекст. 2013. Вип. 16. С. 101-112. 8. Левчук Т. Поетика повтору в поезії Володимира Свідзінського. Волинь філологічна: текст і контекст: зб. наук. праць. Луцьк: Східноевропейський нац. ун-т імені Лесі Українки, 2017. С. 134-143. 9. Лотман Ю. М. О поэтах и поэзии: Анализ поэт. текста. Санкт-Петербург: Искусство-СПб, 1996. 846 с. 10. Мединська А. Концептуальна метафора в ліриці В. Свідзінського. Волинь філологічна: текст і контекст: зб. наук. праць. Луцьк: Східноевропейський нац. ун-т імені Лесі Українки, 2017. С. 143-153. 11. Свідзінський В. С. Твори: У 2 т. / Вид. підготувала Е. Соловей. Київ: Критика, 2004. (Відкритий архів). Т. 1. Поетичні твори. 584 с. 12. Соловей Е. Невпізнаний гість: Доля і спадщина Володимира Свідзінського. Київ: Наук. думка, 2006. 224 с. 13. Старова О. О. Художня концепція смерті-воскресіння в українській міфософській ліриці першої половини XX століття: дис. ... канд. філол. наук.: 10.01.01. Харків, 2011. 226 с. 14. Тимченко А. О. Мотивна структура поезії Володимира Свідзінського: автореф. дис. ... канд. філол. наук: 10.01.01. Харків, 2010. 19 с.

\section{REFERENCES}

1. Barchyshyna, I. (2013). Enzhambeman yak zasib emfatyzatsii epitetnykh struktur u poetychnykh tvorakh M. Voloshyna ta V. Svidzinskoho [Enzhambeman as a means of emphasisizing epithet structures in poetic works by M. Voloshin and V. Svydzinskyi's]. Slovo $i$ chas - Word and time, 2, 60-67 [in Ukrainian]. 2. Bohdan, S. (2017). Zvertannia v poetychnykh tekstakh Volodymyra Svidzynskoho [Applying in poetic texts by Volodymyr Svidzinskyi's]. Volyn filolohichna: tekst i kontekst: $z b$. nauk. prats. - Volyn philological: text and context: a collection of scientific proceedings. (pp. 8-17). Lutsk: Skhidnoevropeiskyi nats. un-t imeni Lesi Ukrainky [in Ukrainian]. 3. Bondarenko, A. I. (2017). Obrazna semantyka temporalnosti ukrainskykh poetychnykh tekstiv XX stolittia v intehratyvnomu vyiavi [Illustrated semantics of temporality of Ukrainian poetic texts of the twentieth century in an integrative manifestation]. Doctor's thesis. Kyiv [in Ukrainian]. 4. Volkovynskyi, O. (2006). Mistse i znachennia epiteta $\mathrm{v}$ arkhitektonitsi balad V. Svidzinskoho [Place and significance of the epithet in the architectonics of the ballad V. Svidzinskyi's]. Naukovi pratsi Kamianets-Podilskoho derzhavnoho universytetu. Filolohichni nauky - Scientific proceedings of the Kamyanets-Podilsky State University. Philological sciences. (Issue 13), (pp. 205-214) [in Ukrainian]. 5. Hromyk, Yu. V. (2003). Dialektni elementy v khudozhnomu movlenni Volodymyra Svidzynskoho [Dialect elements in the artistic speech of Volodymyr Svidzinskyi's]. Tvorchist Volodymyra Svidzynskoho: zb. nauk. prats - Creativity of Volodymyr Svidzinsky: collection of scientific proceedings. (pp. 114-145). Lutsk: RVV «Vezha» Volyn. derzh. un-tu imeni Lesi Ukrainky [in Ukrainian]. 6. Danyliuk, N. O. (2017). Arkhetypni movni obrazy v poezii Volodymyra Svidzinskoho [Archetypal linguistic images in the poetry of Vladimir Svidzinskyi's] Volyn filolohichna: tekst $i$ kontekst: $z b$. nauk. prats - Volyn philological: text and context: a collection of scientific proceedings. (pp. 63-75). Lutsk: Skhidnoevropeiskyi nats. un-t imeni Lesi Ukrainky [in Ukrainian]. 7. Lavrynovych, L. (2013). Modusy chasu u strukturi lirychnykh tvoriv T. Shevchenka [Modus 
of time in the structure of lyrical works by T. Shevchenko]. Volyn filolohichna: tekst i kontekst - Volyn philological: text and context. (Issue 16), (pp. 101-112) [in Ukrainian]. 8. Levchuk, T. (2017). Poetyka povtoru v poezii Volodymyra Svidzynskoho [Poetics of the retelling in the poetry of Volodymyr Svidzinskyi's]. Volyn filolohichna: tekst i kontekst: zb. nauk. prats - Volyn philological: text and context: a collection of scientific proceedings. (pp. 134-143). Lutsk: Skhidnoevropeiskyi nats. un-t imeni Lesi Ukrainky [in Ukrainian]. 9. Lotman, Yu. M. (1996). O poetah i poezii: Analiz poet. teksta [On poets and poetry: Analysis of the poetic text]. Sankt-Peterburh: Yskusstvo-SPb [in Russian]. 10. Medynska, A. (2017). Kontseptualna metafora v lirytsi V. Svidzynskoho [Conceptual metaphor in lyrics by V. Svidzinskyi's]. Volyn filolohichna: tekst $i$ kontekst: $z$ b. nauk. prats - Volyn philological: text and context: a collection of scientific proceedings. (pp. 143-153). Lutsk: Skhidnoevropeiskyi nats. un-t imeni Lesi Ukrainky [in Ukrainian]. 11. Svidzinskyi, V. Ye. (2004). Tvory: U 2 t. [Writings: In 2 vol.] Kyiv: Krytyka [in Ukrainian]. 12. Solovei, E. (2006). Nevpiznanyi hist: Dolia i spadshchyna Volodymyra Svidzinskoho [Unrecognized guest: Vladimir Svidzinsky' fate and heritage]. Kyiv: Nauk. dumka [in Ukrainian]. 13. Starova, O. O. (2011). Khudozhnia kontseptsiia smerti-voskresinnia v ukrainskii mifosofskii lirytsi pershoi polovyny XX stolittia [Literary concept of death-resurrection in Ukrainian mythosophical lyrics of the first half of the XX century] Extended abstract of candidate's thesis. Kharkiv [in Ukrainian]. 14. Tymchenko, A. O. (2010). Motyvna struktura poezii Volodymyra Svidzinskoho [Motive structure of Vladimir Svidzinsky poetry]. Extended abstract of candidate's thesis. Kharkiv [in Ukrainian].

Сметана Ірина Ігорівна - старший викладач кафедри українознавства і мовної підготовки іноземних громадян, Харківський національний економічний університет імені Семена Кузнеця; просп. Науки, 9-А, Харків, Україна.

Tel.: +38-098-859-08-03

E-mail: Iryna.Smetana@hneu.net

https://orcid.org/0000-0002-2974-3348

Smetana Iryna Ihoryvna - Senior Lecturer, Department of Ukrainian Studies and Language Preparation of Foreign Citizens, Kharkiv National University of Economics named after Semen Kuznets; Nauky Av., 9-A, Kharkiv, 61166, Ukraine.

Надійшла до редакції 30 березня 2019 року 